\title{
Effect of Intensity and Duration of Heat-shock Treatments on Wound-induced Phenolic Metabolism in Iceberg Lettuce
}

\author{
Julio G. Loaiza-Velarde, Francisco A. Tomás-Barberá, ${ }^{1}$ and Mikal E. Saltveit \\ Department of Vegetable Crops, Mann Laboratory, University of California, Davis, CA 95616-8631
}

\begin{abstract}
ADDITIONAL INDEX wORDs. browning, Lactuca sativa, PAL, peroxidase activity, phenylalanine ammonia-lyase, polyphenyl oxidase, wound responses

Anstracr. Wounding during minimal processing of lettuce (Lactuca sativa, L.) induces alterations in phenolic metabolism that promote browning and the loss of quality. The activity of phenylalanine ammonia-lyase (PAL; the first committed enzyme in phenylpropanoid metabolism) and the concentration of phenolic compounds (e.g., chlorogenic acid, dicaffeoyl tartaric acid, and isochlorogenic acid) increase in excised iceberg lettuce midrib segments after wounding. The effect of short heat-shock treatments on browning and phenolic metabolism in excised midrib segments of iceberg lettuce was studied. As the heat-shock temperature increased from 20 to $70^{\circ} \mathrm{C}$, there was a decrease in the subsequent increase in PAL activity and the accumulation of phenolic compounds in excised midrib segments. Treatments of $45{ }^{\circ} \mathrm{C} \mathrm{for} 120 \mathrm{~s}, 50{ }^{\circ} \mathrm{C}$ for $60 \mathrm{~s}$, or $55^{\circ} \mathrm{C}$ for $30 \mathrm{~s}$ significantly reduced the increase in PAL activity and subsequent browning seen in control tissue after wounding. Exposure to $45{ }^{\circ} \mathrm{C}$ for $480 \mathrm{~s}, 50{ }^{\circ} \mathrm{C}$ for $60 \mathrm{~s}$, or $55^{\circ} \mathrm{C}$ for $45 \mathrm{~s}$ prevented PAL activity from rising above initial levels. Phenolic compounds remained at initial levels for 3 days in excised midribs exposed to $50{ }^{\circ} \mathrm{C}$ for $90 \mathrm{~s}$ or to $55{ }^{\circ} \mathrm{C}$ for $60 \mathrm{~s}$. However, $55{ }^{\circ} \mathrm{C}$ damaged the tissue, as indicated by a* and $\mathrm{L}^{*}$ Hunter color values. The synthesis of chlorogenic acid, dicaffeoyl tartaric acid, and isochlorogenic acid was greatly reduced by these heat-shock treatments. These treatments also decreased polyphenol oxidase activity and, to a lesser extent, peroxidase activity.
\end{abstract}

Minimal processing of fresh fruit and vegetables involves many mechanical processes (e.g., abrading, cutting, and peeling), which injure the tissue. Such wounding induces alterations in many physiological processes, which often make the processed item more perishable than the unprocessed fresh product and diminish the shelf life of the final minimally processed product (Bolin and Huxoll, 1991). Wounding also elicits several physiological responses associated with wound healing (Brecht, 1995; Saltveit, 1997). Foremost among these reactions are alterations in phenolic metabolism and the concomitant increase in the propensity of the wounded tissue to brown.

The activity of phenylalanine ammonia-lyase (PAL; the first committed enzyme in phenyl propanoid metabolism) and the concentration of phenolic compounds (e.g., chlorogenic acid, dicaffeoyl tartaric acid, and isochlorogenic acid) increase in excised iceberg lettuce midrib segments after wounding (LopezGalvez et al., 1997; Tomás-Barberán et. al., 1997). Methods used to control the increase in phenolic metabolism that leads to browning and loss of quality of minimally processed fresh produce include using reducing agents, enzyme inhibitors, acidulants, and complexing agents (McEvily et al., 1992). Some of these chemical treatments are very effective in controlling browning by interfering with specific metabolic pathways. For instance, obenzylhydroxylamine (Hoagland, 1985), cysteine (Richard-Forget et al., 1992), and some phenylalanine analogues (e.g., 2aminoindan-2-phosphonic acid) (Leubner-Metzger and Amrhein, 1994; Zon and Amrhein, 1992) have been reported to reduce the activity of enzymes associated with phenylpropanoid metabolism (e.g., PAL). However, concern about the use of chemicals and their toxic nature precludes their use on many minimally processed fresh fruit and vegetables. This concern with chemical residues is

Received for publication 6 June 1997. Accepted for publication 8 Aug. 1997. The cost of publishing this paper was defrayed in part by the payment of page charges. Under postal regulations, this paper therefore must be hereby marked advertisement solely to indicate this fact.

${ }^{1}$ Permanent address: CEBAS (CSIC), P.O. Box 4195, Murcia E-30080, Spain. eliminated by using controlled atmospheres (CAs) and modified atmospheres (MAs) - treatments currently used in the commercial packaging of minimally processed lettuce. The physiological effect of CAs and MAs on phenolic metabolism has been explored by Ke and Saltveit (1989) and Siriphanich and Kader (1985).

Other treatments that could be of commercial importance in reducing browning include the parallel induction of a natural PAL inhibitor in lettuce (Ritenour and Saltveit, 1996) and heat shock to redirect protein synthesis (Saltveit, 1997). Wound-induced changes in phenolic metabolism could be eliminated by redirecting protein synthesis away from the production of enzymes associated with phenolic metabolism (e.g., PAL) to the synthesis of heat-shock proteins. It appears that there is a hierarchical response in tissue to several abiotic stresses, with the production of heat-shock proteins superseding the wound induction of enzymes associated with phenolic metabolism (Saltveit, 1997).

The objective of these experiments was to assess the effect of different heat treatments (i.e., temperature and duration) on the phenolic metabolism and browning of iceberg lettuce. This evaluation was achieved by analyzing PAL, polyphenol oxidase (PPO), and peroxidase (POD) enzyme activity and by measuring the concentration of various phenolic compounds previously found to be associated with wound-induced increases in browning potential of lettuce tissue. These findings will help in devising appropriate treatments to extend the shelf life and visual quality of minimally processed lettuce.

\section{Materials and Methods}

Plant material. 'Salinas' iceberg lettuce was used in all experiments. Whole heads of lettuce were purchased from a local wholesale market the day after harvest, transported to the Mann Laboratory, and kept at $0^{\circ} \mathrm{C}$ until used. After discarding wrapper leaves, the next six to eight uninjured leaves were carefully removed and $5 \times 7-\mathrm{cm}$ midrib segments were excised starting $3 \mathrm{~cm}$ from the base of the leaf. Randomized samples of at least three midrib segments were used as replications in each treatment. 
Treatments. Randomly selected groups of three excised midrib segments were immersed in a hot water bath (model 9001; Fisher Scientific) at 20 to $70^{\circ} \mathrm{C}$ in $10^{\circ} \mathrm{C}$ increments. The treatments were for 30 or $60 \mathrm{~s}$. After the heat treatments, the segments were put in $10^{\circ} \mathrm{C}$ water for $30 \mathrm{~s}$. A home salad spinner was used to remove excess water. Segments were then held at $10^{\circ} \mathrm{C}$ in airtight metal boxes. A flow of ethylene-free, humidified air was maintained at a sufficient rate to keep the $\mathrm{CO}_{2}$ level below $0.15 \%$. After $24 \mathrm{~h}$, replicated samples were assayed for PAL activity. Phenolic compounds were extracted and their absorbance was measured at $320 \mathrm{hm}$.

Based on the ability of the previous heat treatments to reduce subsequent browning and PAL activity, three temperatures were selected for more detailed study. Tissue segments were subjected to $45^{\circ} \mathrm{C}$ for 60 to $600 \mathrm{~s}, 50^{\circ} \mathrm{C}$ for 30 to $450 \mathrm{~s}$, and $55^{\circ} \mathrm{C}$ for 15 to $300 \mathrm{~s}$. After $24 \mathrm{~h}$, replicated samples were taken and assayed for PAL activity or frozen at $-80^{\circ} \mathrm{C}$ until analyzed for phenolic content.

Based on the ability of the previous heat treatments to reduce subsequent PAL activity, three time $\times$ temperature heat treatments were selected for more detailed study. Midrib segments were treated at $45^{\circ} \mathrm{C}$ for $120 \mathrm{~s}, 50^{\circ} \mathrm{C}$ for $90 \mathrm{~s}$, and $55^{\circ} \mathrm{C}$ for $60 \mathrm{~s}$. Replicated samples were taken after $24 \mathrm{~h}$ for assays of PAL, PPO, and POD enzyme activity. The determination of absorbance at 320 $\mathrm{nm}, \mathrm{a}^{*}$ and $\mathrm{L}^{*}$ values, and phenolic compounds were also evaluated from samples held for $0,24,48$, and $72 \mathrm{~h}$.

Phenolic compound determination. The procedure for ex-
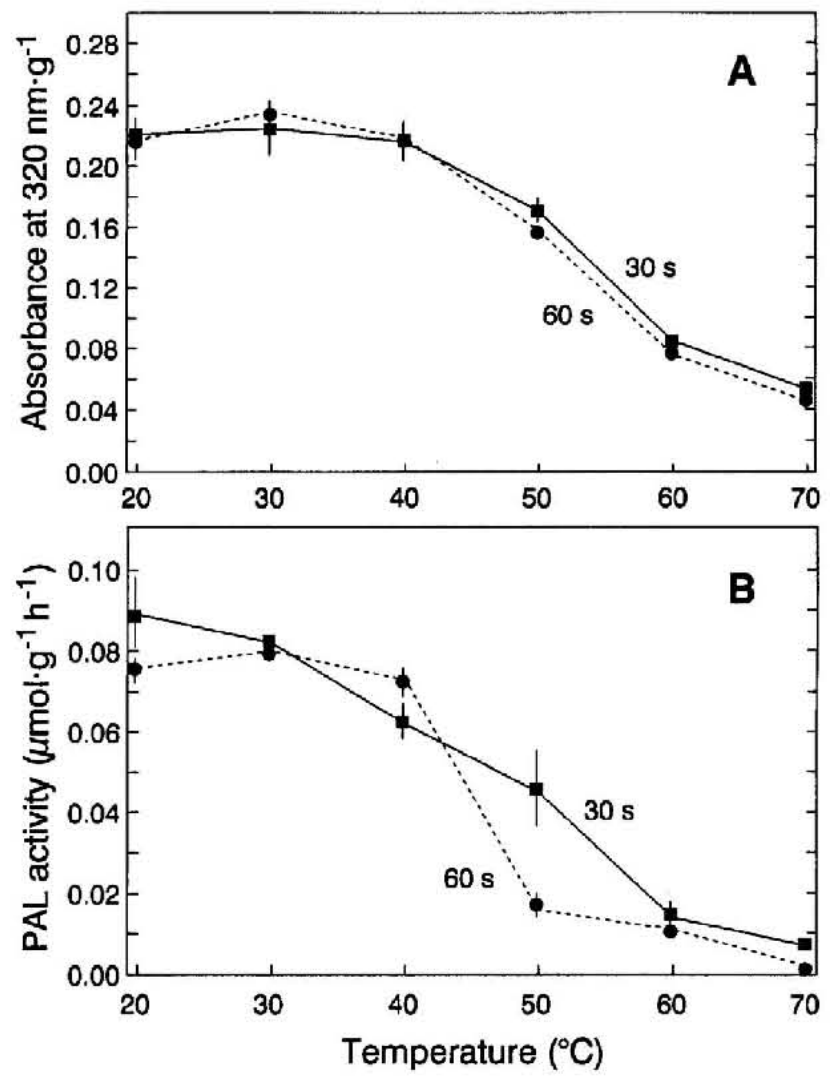

Fig. 1. Effect of temperature $\left(20\right.$ to $70^{\circ} \mathrm{C}$ ) and duration of exposure ( 30 or $\left.60 \mathrm{~s}\right)$ on the subsequent development of browning potential (absorbance at $320 \mathrm{~nm})(\mathbf{A})$ and phenylalanine ammonia-lyase (PAL) activity ( $\mu \mathrm{mol} \cdot \mathrm{g}^{-1} \cdot \mathrm{h}^{-1}$ cinnamic acid) (B) in excised iceberg lettuce midrib segments. Tissues were assayed $24 \mathrm{~h}$ after the temperature treatments. Means \pm SD, SD bars present only when larger than symbol. tracting phenolic compounds was that of Ke and Saltveit (1988); $10 \mathrm{~g}$ of tissue were homogenized with $20 \mathrm{~mL}$ of methanol [highperformance liquid chromatography (HPLC) grade] using an Ultra-Turrax tissue homogenizer at moderate speed for $30 \mathrm{~s}$. The homogenate was filtered through four layers of cheesecloth and centrifuged at $15,000 g_{\mathrm{n}}$ for $15 \mathrm{~min}$. The supernatant was used directly to measure the browning potential of the lettuce tissue. The absorbance of an aliquot of the supernatnat was read at $320 \mathrm{~nm}$ with a UV-VIS recording spectrophotometer (UV-160A; Shimadzu). The same supernatant was also used to prepare the extracts for the HPLC analysis. The preparation of the extracts, HPLC analysis, and identification and quantification of the phenolic compounds were performed as previously described (Tomás-Barberán et al., 1997).

Evaluation of $a^{*}$ and $L^{*}$ values. To determine the $a *$ and $L^{*}$ values, the remnants from the filtration of the phenolic extraction were placed in a transparent multiwell tissue culture plate. Upon drying, $\mathrm{a}^{*}$ and $\mathrm{L}^{*}$ values were measured with a chromameter (CR200 ; Minolta) after calibrating with a white plate $\left(L^{*}=97.63 ; a^{*}\right.$ $=-0.53 ; b^{*}=2.38$ ).

ENZYME ASSAYs. PAL activity was assayed as previously described (Ke and Saltveit, 1986). PPO was extracted as previously reported (Siriphanich and Kader, 1985) with modifications. In our studies, the buffer was $50 \mathrm{~mm}$ potassium phosphate ( $\mathrm{pH}$ 6.2). PPO activity was assayed as previously described (Couture et al., 1993). Soluble and ionically bound POD were extracted as previously described (Thomas et al., 1981). POD activity was assayed using $50 \mathrm{~mm}$ phosphate buffer ( $\mathrm{pH} 6.4$ ), $0.1 \mathrm{M}$ guaiacol, and $0.25 \% \mathrm{H}_{2} \mathrm{O}_{2}$. The absorbance was read at $420 \mathrm{~nm}$ at $18^{\circ} \mathrm{C}$.

STATISTICAL ANALYSIS. The results reported in this paper are the mean values of duplicate samples accompanied by their standard deviations. All experiments were performed more than once. Even though slight variations existed from experiment to experiment, identical trends were detected.

\section{Results}

Exposure to 20 to $40{ }^{\circ} \mathrm{C}$ for 30 or $60 \mathrm{~s}$ did not produce a significant alteration in the subsequent accumulation of phenolic compounds (i.e., browning potential after 24 h) (Fig. 1A). However, increasing the temperature from 40 to $70^{\circ} \mathrm{C}$ produced a moderately steady decrease in the absorbance at $320 \mathrm{~nm}$ (i.e., the maximum absorbance for caffeic acid derivatives) for both durations of exposure. A similar decline in subsequent PAL activity was observed with increasing temperature (Fig. 1B). In this case, the 60 -s exposure produced a steeper decline between 40 and $50^{\circ} \mathrm{C}$ than the 30 -s exposure. Exposure to 60 and $70^{\circ} \mathrm{C}$ for $30 \mathrm{~s}$ injured the tissue, as evidenced by the fact that the lettuce tissue became subsequently translucent. PAL activity after the $70{ }^{\circ} \mathrm{C}, 60 \mathrm{~s}$ treatment was hardly detected, which also implied extensive damage to the synthetic pathways in the tissue by these high temperatures.

The effect of temperature exposure was studied further at 45 , 50 , and $55^{\circ} \mathrm{C}$ (Fig. 2). At each temperature there was a decrease in PAL activity with increasing duration of treatment. The reduction in subsequent PAL activity was also faster at the higher temperature; i.e., it took $360 \mathrm{~s}$ at $45^{\circ} \mathrm{C}$ to accomplish the same reduction produced by $60 \mathrm{~s}$ at $50^{\circ} \mathrm{C}$. Exposing the midribs to $55^{\circ} \mathrm{C}$ for $45 \mathrm{~s}$ prevented PAL activity from increasing beyond the levels measured in the controls at the beginning of the experiment. The same effect was produced by exposure to $45^{\circ} \mathrm{C}$ for $480 \mathrm{~s}$ or to 50 ${ }^{\circ} \mathrm{C}$ for $60 \mathrm{~s}$.

Selected combinations of duration and temperature were cho- 


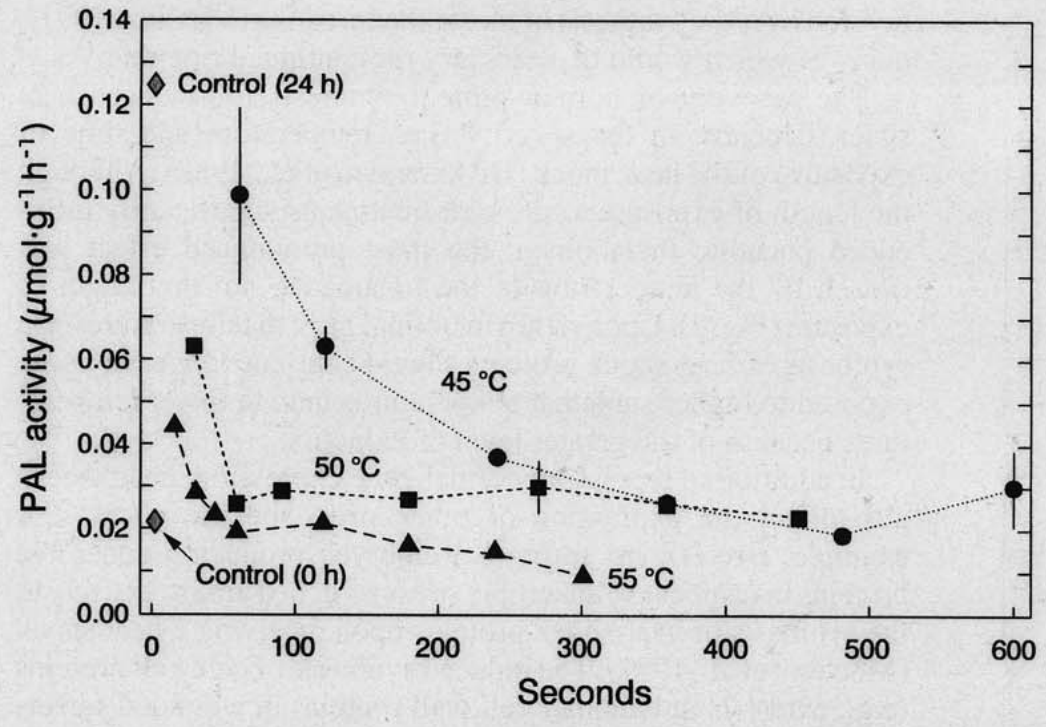

Fig. 2. Effect of duration of exposure to selected temperatures on the subsequent development of phenylalanine ammonia-lyase (PAL) activity $\left(\mu \mathrm{mol} \cdot \mathrm{g}^{-1} \cdot \mathrm{h}^{-1}\right.$ cinnamic acid) in excised iceberg lettuce midrib segments. Control midrib segments were assayed before treatment $(0 \mathrm{~h})$ and after $24 \mathrm{~h}$ at $10^{\circ} \mathrm{C}(24 \mathrm{~h})$. Means $\pm \mathrm{SD}$, SD bars present only when larger than symbol.

sen $\left(45^{\circ} \mathrm{C}\right.$ for $120 \mathrm{~s}, 50^{\circ} \mathrm{C}$ for $90 \mathrm{~s}$, and $55^{\circ} \mathrm{C}$ for $\left.60 \mathrm{~s}\right)$ for subsequent experiments. PAL, PPO, and POD, (i.e., enzymes that participate in phenolic metabolism in fruit and vegetables) were analyzed individually and the results are expressed as the percentage of activity of the control after $24 \mathrm{~h}$ (Fig. 3). The greatest effect of the heat treatment was on PAL activity. Temperatures of 50 and $55^{\circ} \mathrm{C}$ reduced PAL activity $\approx 90 \%$. A more consistent pattern in reduction was observed for PPO activity, which was reduced $25 \%$ at $45{ }^{\circ} \mathrm{C}, 50 \%$ at $50{ }^{\circ} \mathrm{C}$, and $65 \%$ at $55^{\circ} \mathrm{C}$. For POD there was a uniform decrease in activity of $\approx 30 \%$ from the control for each of the three temperature $x$ time treatments. Only the results for soluble peroxidase are reported; the ionically bound peroxidase was assayed but there was no significant difference among the treatments (data not shown). POD is relatively heat stable and its activity is commonly measured to determine an adequate blanching treatment for fruit and vegetables. It also participates in the formation of lignin, which is one of the latter reactions in the wound healing process. Higher temperatures or extended durations of exposure may have further reduced POD activity; but, as we observed, higher temperatures also would have injured the lettuce tissue.

After $3 \mathrm{~d}$, the browning potential (i.e., absorbance of the methanol extract at $320 \mathrm{~nm}$ ) was similar to the initial value for the $50{ }^{\circ} \mathrm{C}, 90 \mathrm{~s}$ treatment (Fig. 4A). When treated at $55^{\circ} \mathrm{C}$ for $60 \mathrm{~s}$, the browning potential declined $25 \%$ below the initial level. This decline could be related to an interconversion of phenolic compounds since PAL activity was similar for both treatments. Even though the $55^{\circ} \mathrm{C}, 60 \mathrm{~s}$ treatment was best at attenuating phenolic metabolism in lettuce, it also damaged the tissue. Tissue injury was observed when the greenness ( $a^{*}$ value) and lightness ( $\mathrm{L}^{*}$ value) were evaluated (Fig. $4 \mathrm{~B}$ and $\mathrm{C}$ ). The $\mathrm{a}^{*}$ value is highly correlated with visual quality of lettuce (López-Gálvez et al., 1996). Control midribs and midribs exposed to $45^{\circ} \mathrm{C}$ for $120 \mathrm{~s}$ lost greenness and became darker (Fig. $4 \mathrm{~B}$ and C). The $50^{\circ} \mathrm{C}, 90$ s treatment kept the greenness and lightness of the tissue over the span of the experiment. The damaging effect of the $55{ }^{\circ} \mathrm{C}, 60 \mathrm{~s}$ treatment is reflected by the lower $\mathrm{L}^{*}$ value that was apparent after the treatment.

The same phenolic compounds previously identified by Tomás-Barberán et al. (1997) in wounded lettuce tissue were detected in this experiment. Total phenolic levels (Fig. 5) and levels of caffeoyl tartaric acid, 5caffeoyl quinic acid (chlorogenic acid), dicaffeoyl tartaric acid, and 3,5-dicaffeoyl quinic acid (isochlorogenic acid) (Fig. 6) were significantly effected by the temperature treatments. In accordance with data presented in Fig. $4 \mathrm{~A}$, the best temperature $\times$ time treatments that reduced the increase in the concentration of phenolic compounds were $50^{\circ} \mathrm{C}$ for $90 \mathrm{~s}$ and $55^{\circ} \mathrm{C}$ for $60 \mathrm{~s}$. The concentration of each phenolic compound was maintained at the same or slightly lower level than at the beginning of the experiment by the $55^{\circ} \mathrm{C}, 60 \mathrm{~s}$ treatment.

The main phenolic compounds were chlorogenic acid and dicaffeoyl tartaric acid, both of which accumulated to $\approx 25 \mathrm{mg} \cdot \mathrm{g}^{-1}$ in the control tissue by day 3 (Fig. 6 ). The increase with time for chlorogenic and isochlorogenic acid was progressively reduced by increasing temperatures. Exposure to 50 ${ }^{\circ} \mathrm{C}$ for $90 \mathrm{~s}$ maintained the level of these two compounds at initial levels for the duration of the experiment. The concentration of caffeoyl tartaric acid ranged from 3.5 to $7.5 \mathrm{mg} \cdot \mathrm{g}^{-1}$ throughout the experiment for all treatments. The levels of caffeoyl tartaric acid remained at initial levels in tissue exposed to either $45^{\circ} \mathrm{C}$ for 120 s or $50^{\circ} \mathrm{C}$ for $90 \mathrm{~s}$, while it decreased in tissue exposed to $55^{\circ} \mathrm{C}$ for $60 \mathrm{~s}$. This decrease was puzzling since it also initially occurred in control tissue; however, by day 3 the levels started to rise in control tissue while they showed an additional decrease in the $55^{\circ} \mathrm{C}, 60 \mathrm{~s}$ treated tissue. Levels of dicaffeoyl tartaric acid were similar in all treatments for the first $2 \mathrm{~d}$. By day 3 , levels of dicaffeoyl tartaric acid had more than doubled in control tissue while they had remained about the same in all temperature treated tissue.

Fig. 3. Effect of selected time $\times$ temperature treatments on the subsequent activity of phenylalanine ammonia-lyase (PAL), polyphenol oxidase (PPO), and peroxidase (POD) in excised iceberg lettuce midrib segments. Enzyme activities were assayed in tissue $24 \mathrm{~h}$ after the temperature treatments. Control midribs were held at $10^{\circ} \mathrm{C}$ after excision. The line atop each bar represents the SD of the mean.

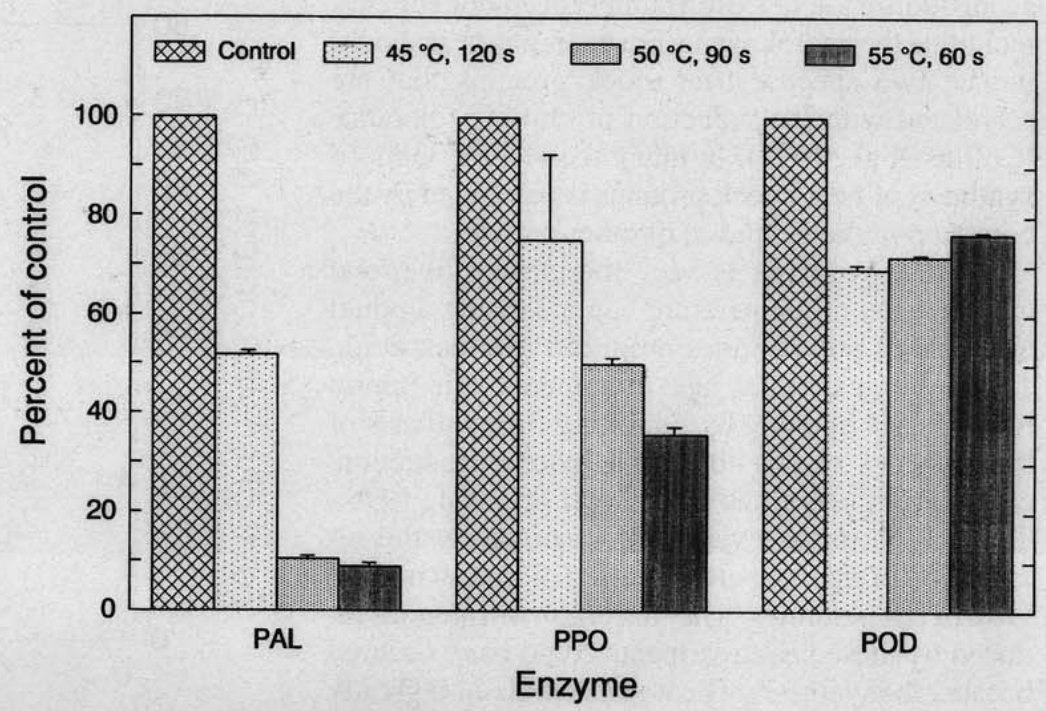




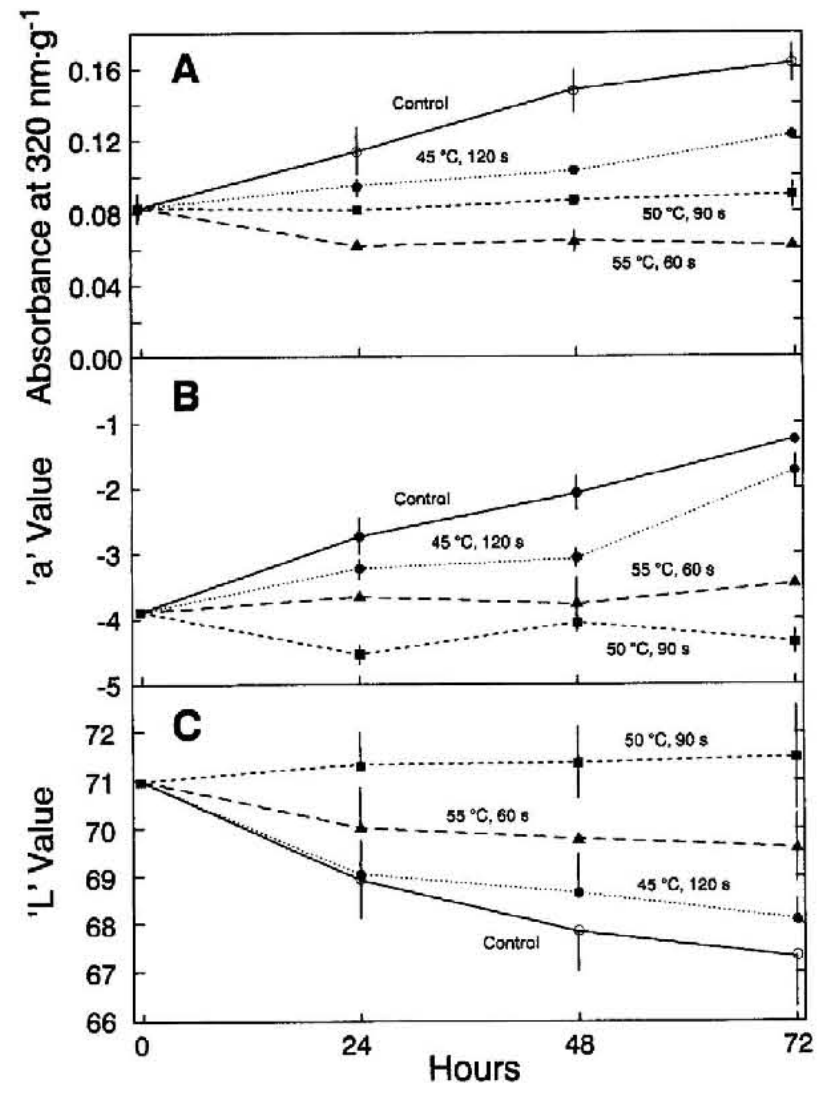

Fig. 4. Effect of selccted time $\times$ temperature treatments on the subsequent browning as measured by the absorbance at $320 \mathrm{~nm}$ (A), change in green color as measured by the $\mathrm{a}^{*}$ value $(\mathbf{B})$, and lightness as measured by decreases in the $\mathrm{L}^{*}$ value $(\mathbf{C})$ of excised lettuce midrib segments. Means \pm SD, SD bars present only when larger than symbol.

\section{Discussion}

The heat-shock response occurs when living cells are exposed to temperatures $\approx 10^{\circ} \mathrm{C}$ higher than their normal growth temperature (Vicrling, 1991). This ubiquitous response to temperature stress occurs in all biological organisms and features selective transcription and translation of a group of highly conserved heatshock genes (Howarth and Ougham, 1993). The induced synthesis of unique heat-shock proteins is correlated with the acquisition of tolerance to a number of abiotic stresses, including thermotolerance. For example, heat shocks induce two specific heat-shock proteins that are correlated with the induction of chilling tolerance (Collins et al., 1995). In many tissues, the induced synthesis of heat-shock proteins is paralleled by the cessation of the synthesis of other proteins.

Protein synthesis is very thermosensitive, and any changes in temperature can affect the amount and type of polypeptides produced (Pollock et al., 1993). For example, heat treatments can inhibit tomato fruit ripening by inhibiting the synthesis of the enzymes responsible for ethylene production, color development, and softening (Lurie et al., 1996). This inhibition is reversible, as shown by the resumption of ripening after a period of time at normal growth temperatures. The inhibition of ripening induced by these heat treatments could have occured because the synthesis of heat-shock proteins is greatly favored over the synthesis of most other proteins (Vierling, 1991), many of which would be necessary for continued ripening.

The recovery of normal protein synthesis following a heat shock depends on the severity (i.e., temperature and time of exposure) of the heat shock (DiDomenico et al., 1982). Although the length of exposure to the heat treatments significantly influenced phenolic metabolism, the most pronounced effect was caused by the temperature of the treatments, not the length of exposure (Fig. 2). Upon return to normal growth temperatures, the synthesis of heat-shock proteins should continue longer in tissue exposed to higher sublethal temperatures than to lower temperatures because of the greater level of induction.

In addition to repressing normal genc expression, heat shocks also affect the expression of other stress-specific genes. For example, rice (Oryza sativa L.) embryos producing anaerobic proteins in response to anaerobic stress switched almost entirely to the synthesis of heat-shock proteins upon receiving a heat shock (Mocquot et al., 1987). The induced synthesis of cell wall proteins (e.g., extensin and another cell wall protein) in wounded carrots (Daucus carota L) ceased upon application of heat treatments at 40 ${ }^{\circ} \mathrm{C}$ (Brodl and Ho, 1992).

Wounding is a common abiotic stress that induces altered protein synthesis in minimally processed fruit and vegetables (Saltveit, 1997). Even slight mechanical injury induces the synthesis of enzymes responsible for ethylene biosynthesis in plants (Abeles et al., 1992). The wounding of lettuce tissue induces the de novo synthesis of PAL, which initiates the reactions that lead to an increase in the level of phenolic compounds and browning (Ke and Saltveit, 1989).

If plant tissues show a hierarchical response to different abiotic stresses, as proposed by Saltveit (1997), then it would be possible to redirect the synthesis of proteins in lightly processed lettuce from those related to wounding to those related to heat shock. In this way, the synthesis of enzymes that participate in woundinduced phenylpropanoid metabolism would be partially or completely repressed in favor of heat-shock proteins, and the browning of cut lettuce would consequently be reduced. This proposition is supported by results presented in this paper. The activities of PAL

Fig. 5. Change in total phenolic content of excised midrib segments over time after cxposure to $45^{\circ} \mathrm{C}$ for $120 \mathrm{~s}, 50^{\circ} \mathrm{C}$ for $90 \mathrm{~s}, 55^{\circ} \mathrm{C}$ for $60 \mathrm{~s}$, or continuous $10^{\circ} \mathrm{C}$ (control). Means \pm SD, sD bars present only when larger than symbol.

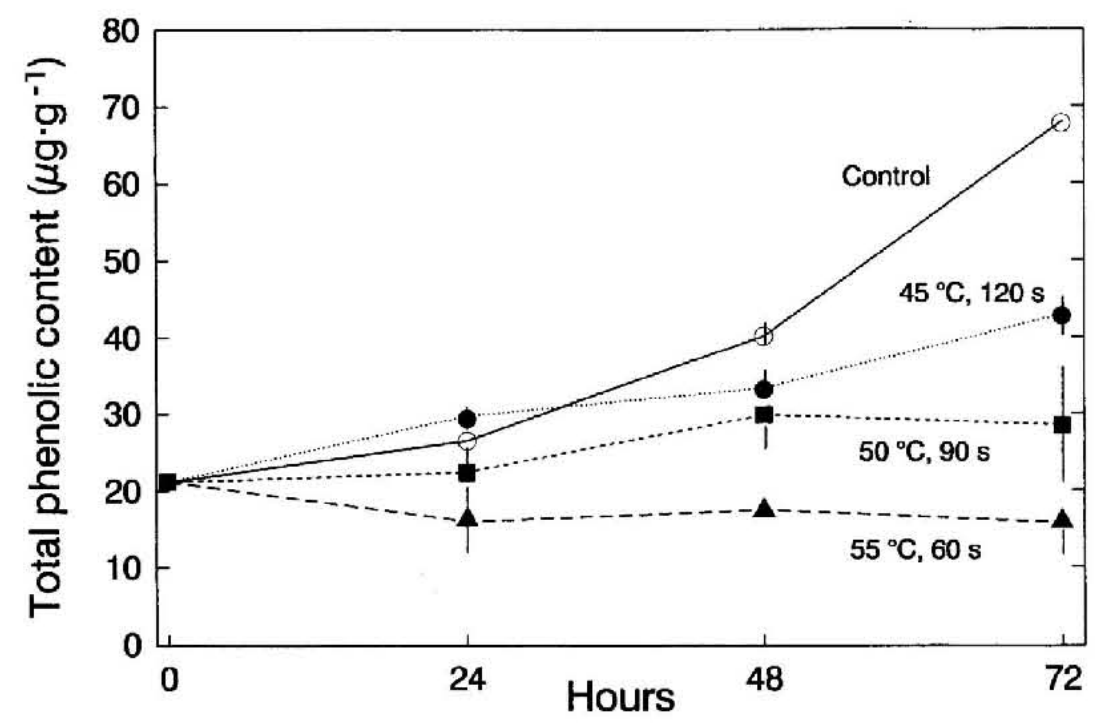




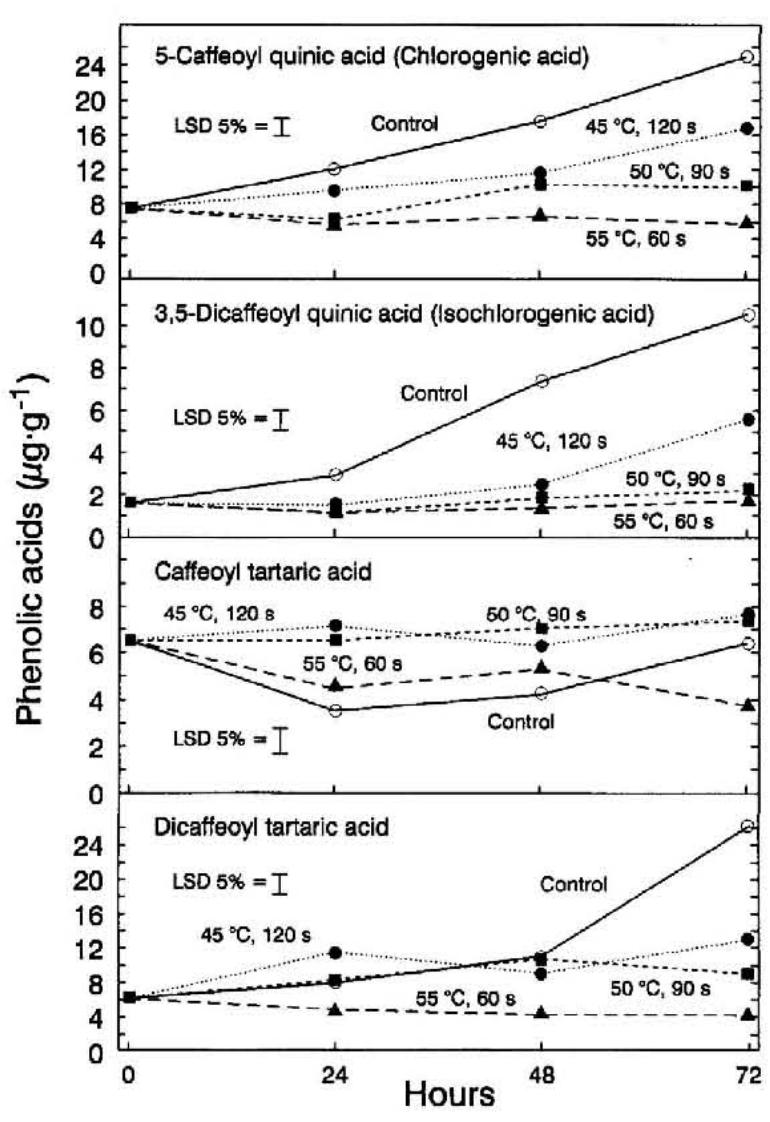

Fig. 6. Change in the content of four caffeic acid derivatives (caffeoyl quinic acid, dicaffeoyl quinic acid, caffeoyl tartaric acid, and dicaffeoyl tartaric acid) in excised midrib segments after exposure to $45^{\circ} \mathrm{C}$ for $120 \mathrm{~s}, 50^{\circ} \mathrm{C}$ for $90 \mathrm{~s}, 55^{\circ} \mathrm{C}$ for $60 \mathrm{~s}$, or $10^{\circ} \mathrm{C}$ continuously (control). The bars represent the $5 \%$ iss values.

and PPO, two of the major enzymes responsible for browning, were affected by increasing temperatures in the heat treatments (i.e., $45<50<55^{\circ} \mathrm{C}$ ). Data presented on browning (Fig. 4) and on the accumulation of phenolic compounds (Figs. 5 and 6) are consistent with the proposal that heat shock represses the synthesis of wound-induced enzymes of phenylpropanoid metabolism and favors the synthesis of heat-shock proteins. Using a stress that induces innocuous changes to circumvent the objectionable effects of another stress may be a technique worth developing for a number of other applications.

\section{Literature Cited}

Abeles, F.B., P.W. Morgan, and M.E. Saltveit. 1992. Ethylene in plant biology. 2nd ed. Academic Press, New York.

Brecht, J.K. 1995. Physiology of lightly processed fruits and vegetables. HortScience 30:18-22.

Bolin, H.R. and C.C. Huxsoll. 1991. Effect of preparation procedures and storage parameters on quality retention of salad-cut lettuce. J. Food Sci. $56: 60-67$

Brodl, M.R. and T.D. Ho. 1992. Heat shock in mechanically wounded carrot disks causes destabilization of stable secretory protein mRNA and dissociation of endoplasmic reticulum lamellae. Physiol. Plant. 86:253262 .
Collins, G.G., X.L. Nie, and M.E. Saltveit. 1995. Heat shock proteins and chilling injury of mung bean hypocotyls. J. Expt. Bot. 46:795-802

Couture, R., M.I. Cantwell, D. Ke, and M.E. Saltveit. 1993. Physiological attributes and storage life of minimally processed lettuce. HortScience 28:723-725

DiDomenico, B.J., G.E. Bugaisky, and S. Lindquist. 1982. The heat shock response is self-regulated at both the transcriptional and posttranslational level. Cell 31:593-603.

Hoagland, R.E. 1985. O-benzylhydroxylamine: An inhibitor of phenylpropanoid metabolism in plants. Plant Cell Physiol. 26:13531359.

Howarth, C.J. and H.J. Ougham. 1993. Gene expression under temperature stress. New Phytol. 125:1-26.

Ke, D. and M.E. Saltveit. 1986. Effects of calcium and auxin on russet spotting and phenylalanine ammonia-lyase activity in iceberg lettuce. HortScience. 21:1169-1171.

Ke, D. and M.E. Saltveit. 1988. Plant hormone interaction and phenolic metabolism in the regulation of russet spotting in iceberg lettuce. Plant Physiol. 88:1136-1140.

Ke, D. and M.E. Saltveit. 1989. Regulation of russet spotting, phenolic metabolism, and IAA oxydase by low oxygen in iceberg lettuce. J. Amer. Soc. Hort. Sci. 114:638-642.

Leubner-Metzger, G. and N. Amrhein. 1994. Phenylalanine analogues: Potent inhibitors of phenylalanine ammonia-lyase are weak inhibitors of phenylalanine-tRNA synthetases. Z. Naturforsch. 49c, 781-790.

Lopez-Galvez, G., M.E. Saltveit, and M. Cantwell. 1997. Wound-induced phenylalanine ammonia lyase activity: Factors affecting its induction and correlation with the quality of minimally processed lettuce. Postharvest Biol. Technol. 9:223-233.

Lurie, S., A. Handros, E. Fallik, and R. Shapira. 1996. Reversible inhibition of tomato fruit gene expression at high temperature. Plant Physiol. 110:1207-1214.

McEvily, A.J., R. Iyengar, and W.S. Otwell. 1992. Inhibition of enzymatic browning in foods and beverages. Critical Rev. Food Sci. Nutr. 32:253273.

Mocquot, B., B. Ricard, and A. Pradet. 1987. Rice cmbryos can express heat shock genes under anoxia. Biochimie 69:677-682.

Pollock, C.J., C.F. Eagles, C.J Howarth, P.H.D. Schünmann, and J.L. Stoddart. 1993. Temperature stress, p. 109-132. In: L. Fowden, T. Mansfield, and J. Stoddart (eds.). Plant adaptation to environmental stress. Chapman \& Hall, New York.

Richard-Forget, F.C., P.M. Goupy, and J.J. Nicolas. 1992. Cysteine as an inhibitor of enzymatic browning. II. Kinetic studies. J. Agr. Food Chem. 40:2108-2113.

Ritenour, M.A. and M.E. Saltveit. 1996. Identification of a phenylalanine ammonia-lyase inactivating factor in harvested iceberg lettuce (Lactuca sativa L.). Physiol. Plant. 97:327-331.

Saltveit, M.E. 1997. Physical and physiological changes in minimally processed fruits and vegetables, p. 205-220. In: F.A. Tomás-Barberán (ed.). Phytochemistry of fruit and vegetables. Oxford University Press, Oxford, U.K.

Siriphanich, J. and A.A. Kader. 1985. Effects of $\mathrm{CO}_{2}$ on total phenolics, phenylalanine ammonia lyase, and polyphenol oxidase in lettuce tissue. J. Amer. Soc. Hort. Sci. 110:249-253.

Thomas, R.L., J.J. Jen, and C.V. Morr. 1981. Changes in soluble and bound peroxidase-IAA oxidase during tomato fruit development. J. Food Sci. 47:158-161.

Tomás-Barberán, F.A., J. Loaiza-Velarde, A. Bonfanti, and M.E. Saltveit. 1997. Early wound- and ethylene-induced changes in phenylpropanoid metabolism in harvested lettuce. J. Amer. Soc. Hort. Sci. 122:399-404. Vierling, E. 1991. The roles of heat shock proteins in plants. Annu. Rev. Plant Physiol. Plant Mol. Biol. 42:579-620.

Zon, J. and N. Amrhein. 1992. Inhibitors of phenylalanine ammonialyase: 2 -aminoindan-2-phosphonic acid and related compounds. Licbigs Ann. Chem. 625-628. 